\title{
Topically applied methyl nicotinate evokes a temporary inflammation on human skin
}

\author{
Metilnicotinato aplicado topicamente evoca uma inflamação temporária na pele humana \\ Sérgio Faloni de Andrade*, Clemente Rocha, Luis Monteiro Rodrigues \\ Universidade Lusófona - CBIOS - Research Center for Biosciences and Health Technologies, Av. Campo Grande, 376, \\ 1749-024, Lisboa, Portugal \\ *corresponding author: sergio.andrade@ulusofona.pt
}

\begin{abstract}
Some challengers such as methylnicotinate $(\mathrm{MN})$ have been used in human models to study the anti-inflammatory effect of topical formulations. However, MN skin responses are still poorly understood and widely varied. In the present study we aim to contribute to better characterise those responses. Eight healthy participants were selected. All procedures were approved by the institutional Ethics Committee. Two aqueous MN dilutions ( $0.5 \%$ and $1.0 \%)$ were left in contact for 1 minute in the anterior forearm skin. Following exposure, skin reactions were clinically and biometrically assessed at 30, 60 and 120 minutes and compared with baseline. Measurements involved the ICDRG clinical score scale and select analytical technologies - laser Doppler flowmetry, Polarised Spectroscopy, Transepidermal Water Loss Meter, and High Resolution Sonography. Results have shown that MN application evoked a maximal response at 30 minutes with an increase in the ICDRG score between 1-2. Significant changes in TEWL and microcirculation were observed, as was an increased dermal hypoecogenicity (edema), detected by HRS. These effects are compatible with a localised shortduration inflammation and reinforce the interest of $\mathrm{MN}$ to be used as a safe and controllable challenger in human models.
\end{abstract}

Keywords: Methyl Nicotinate, in vivo human skin, microcirculation, TEWL, inflammation

\begin{abstract}
Resumo
Algumas substâncias, como o metilnicotinato (MN), têm sido usados em experimentos de provocação na pele humana para estudar o efeito anti-inflamatório de formulações tópicas. No entanto, as respostas da pele ao MN ainda são pouco conhecidas e amplamente variadas. No presente estudo pretendemos contribuir para melhor caracterizar essas respostas. Oito participantes saudáveis foram selecionados. Todos os procedimentos foram aprovados pelo Comitê de Ética institucional. Duas diluições aquosas de MN $(0,5 \%$ e $1,0 \%)$ foram colocadas em contacto com a pele do antebraço por 1 minuto. Após a exposição, as reações cutâneas foram avaliadas clínica e biometricamente nos tempos 30, 60 e 120 minutos e comparadas com a linha de base. As medições envolveram a escala de pontuação clínica do ICDRG e outras tecnologias - fluxometria por laser Doppler, espectroscopia polarizada, medida da perda de água transepidérmica (PTEA) e Ultra-Sonografia de Alta Resolução (USAR). Os resultados mostraram que a aplicação de MN evocou uma resposta máxima após 30 minutos. com um aumento no escore ICDRG entre 1-2. Também provocou mudanças significativas na PTEA, microcirculação e um aumento da hipoecogenicidade dérmica (edema) detectado por USAR. Esses efeitos são compatíveis com uma inflamação localizada de curta duração e reforçam a utilidade do MN para usado como um desafiador seguro e controlável em modelos humanos.
\end{abstract}

Palavras-chave: Metilnicotinato, pele humana in vivo, microcirculação, Perda Transepidérmica de água, inflamação 


\section{Introduction}

Inflammation is a key feature in clinical dermatology, with an enormous variety of factors and mechanisms affecting skin inflammatory processes and their clinical expression in terms of signs and subjective symptoms. These complicated interactions between skin and the immune system and skin and the nervous system, sometimes referred to as the neuro-immuno-cutaneous (NIC) system are probably a major component of this reality still far from being fully understood (1-3). From the therapeutic point of view this is a remarkable target for pharma and skin care industries since inflammatory disorders are present during the whole human lifecycle, from the newborn to the elderly (4-6). Market demand is growing widely, such that "over-the-counter" medicines and cosmetics are among the consumers' preference all over the world, reflecting also easy access and product satisfaction $(7,8)$.

The systematic investment in the safety evaluation of dermatological products before market introduction partially explains this success. In the post-animal-ban testing era, many new approaches for skin irritation testing and risk assessment were proposed in vitro, primarily in human $(9,10)$. Several challengers were progressively developed to assess, again in human, the effectiveness of anti-inflammatory formulations, such as the anionic detergent sodium lauryl sulfate (SLS), benzoic acid, sorbic acid, methyl nicotinate (MN). Some mechanical approaches (friction, abrasive grains, tape-striping) have also been proposed and used as irritants $(11,12)$. A remarkable amount of experimental information accumulated around SLS and MN have led these compounds to be regarded as safe and capable of reproducing a controlled "inflammation-like" state useful for safety and efficacy assessments of many topical products (12-15). However, data shows that SLS is a strong skin irritant which deforms cell membrane proteins, especially when applied under occlusion ( $0.5 \%$ dilutions and higher), provoking an intense, clinically variable, and lasting aggression to the skin not without risk or/and discomfort. (16-18). In turn, $\mathrm{MN}$ is a nicotinic acid derivative whose vasodilator capacity seems to be of multifactorial origin $(19,20)$. MN, as benzoic acid, sorbic acid, and nicotinic acid derivatives, is able to provoke nonimmunologic contact urticaria

\section{Introdução}

Ainflamação é uma característica chave em dermatologia clínica, apesar de existir uma enorme variedade de fatores e mecanismos que afetam os processos inflamatórios da pele e sua expressão clínica em termos de sinais e sintomas subjetivos. Estas interações complexas entre a pele e o sistema imunológico e a pele e o sistema nervoso, às vezes referidas como sistema neuro-imuno-cutâneo (NIC) são provavelmente uma componente importante de uma realidade ainda longe de ser totalmente compreendida (1-3). Do ponto de vista terapêutico, este é um alvo notável para as indústrias farmacêutica e de cuidados com a pele, pois os distúrbios inflamatórios estão literalmente presentes durante todo o ciclo de vida humana, desde o indivíduo recém-nascido até o idoso (4-6). De fato, este é um amplo mercado de demanda crescente onde os medicamentos e cosméticos "de venda livre" estão entre as preferências dos consumidores em todo o mundo, reflexo também do fácil acesso e satisfação de uso $(7,8)$.

O investimento sistemático na avaliação de segurança dos produtos dermatológicos antes da introdução no mercado explica parcialmente este sucesso. $\mathrm{Na}$ era pós-proibição de testes em animais, muitas novas abordagens para testes de irritação da pele e avaliação de risco foram propostas in vitro, mas principalmente em humanos $(9,10)$. Várias substâncias desafiadoras foram progressivamente desenvolvidas para avaliar, em humanos, a eficácia de formulações anti-inflamatórias como o detergente aniônico sulfato de sódio laurílico (SLS), ácido benzóico, ácido sórbico, metilnicotinato (MN). Algumas abordagens mecânicas (fricção, grãos abrasivos, fitas adesivas) também têm sido propostas e utilizadas como irritantes $(11,12)$. Nesse contexto, há uma quantidade notável de informações experimentais acumuladas em torno de SLS e MN as quais são consideradas seguras e capazes de produzir uma "inflamação" controlada, útil para a avaliação da segurança e eficácia de produtos de uso tópico (1215). Entretanto, os dados mostram que o SLS é um forte irritante que causa deformação das proteínas da membrana celular, especialmente quando aplicado sob oclusão (diluições de $0,5 \%$ e superiores), provocando uma intensa agressão à pele, clinicamente variável e duradoura com riscos e/ou desconforto associados. (16-18). Por sua vez, o MN é um derivado do ácido nicotínico cuja capacidade vasodilatadora parece ser de origem multifatorial $(19,20)$. O MN, assim como o ácido benzóico, ácido sórbico e derivados do ácido nicotínico, é capaz de provocar urticária de contato 
(NICU), the most common form of immediate contact reaction resulting in a rapid inflammatory response without the requirement of previous sensitization. Both challengers (SLS and MN) have also been long questioned for reproducibility (11). Their mechanisms of action and factors that condition individual reactions have not been completely identified (20-23).

Nevertheless, these models have added an enormous amount of valuable scientific knowledge for physiological-pharmacological and toxicological research, even if still far from being complete. In the present study, we try to look further into theaction mechanisms of $\mathrm{MN}$ in human in vivo skin using different non-invasive technologies.

\section{Materials and Methods}

\section{Participants}

Eight healthy individuals, both sexes (three men and five women), ages between 20 and 59 years old (mean $41.37 \pm 11.32$ years old) were selected according to previously defined inclusion/non-inclusion criteria, namely (i) no visible cutaneous lesions and no past or present record of dermatological disease or atopy, (ii) no application of any cosmetics in the test area 48 hours prior to the study at baseline, and (iii) absence of any pharmacological treatment that might interfere with measurements All procedures observed the principles of good clinical practice of the Helsinki Declaration and respective amendments (24) and included informed written consent. The study was previously approved by the institutional Ethical Committee.

\section{Experimental}

Two aqueous MN dilutions of $0.5 \%$ or $1.0 \%$ were randomly applied (in the form of soaked $5 \mathrm{~mm}$ diameter paper discs) in pre-defined areas $\left(1 \mathrm{~cm}^{2}\right)$ of the anterior aspect of the forearm with no occlusion. The dilutions remained in contact with the skin for 1 minute before removal. A similar empty area in the same forearm was used as a negative control. Skin functional variables were measured by non-invasive technologies at time 0 (control) and after MN contact at 30, 60, and 120 minutes. não imunológica (UCNI), que consiste na forma mais comum de reacção de contato imediato, resultando em uma resposta inflamatória rápida que não requer uma sensibilização prévia. Ambos os testes também têm sido questionados há muito tempo por sua reprodutibilidade (11), o que também significa que seus mecanismos de ação não são completamente entendidos (20-23).

No entanto, estes modelos permitiram acrescentar uma enorme quantidade de conhecimentos científicos valiosos para pesquisas fisiológico-farmacológicas e toxicológicas ainda longe de serem concluidas. No presente estudo, tentamos aprofundar o conhecimento dos mecanismos de ação MN na pele humana in vivo, utilizando diferentes tecnologias não-invasivas.

\section{Materiais e Métodos}

\section{Participantes}

Oito indivíduos saudáveis, de ambos os sexos (três homens e cinco mulheres), com idades entre 20 e 59 anos (média 41,37 $\pm 11,32$ anos) foram selecionados de acordo com os critérios de inclusão/não inclusão previamente definidos, nomeadamente: (i) sem lesões cutâneas visíveis e nenhum registo passado ou presente de doença dermatológica ou atopia, (ii) nenhuma aplicação de qualquer cosmético na área de teste 48 horas antes do início do estudo, e (iii) ausência de qualquer tratamento farmacológico que possa interferir com as medições. Todos os procedimentos seguiram os princípios de boa prática clínica da Declaração de Helsinquia e respectivas emendas (24) e incluiu um consentimento informado escrito. O estudo foi previamente aprovado pelo Comitê de Ética Institucional.

\section{Experimental}

Duas soluções aquosas de MN (0,5\% ou 1,0\%) foram aplicadas aleatoriamente (imersão em um disco de papel de $5 \mathrm{~mm}$ de diâmetro) em áreas pré-definidas $\left(1 \mathrm{~cm}^{2}\right)$ da face anterior de um dos antebraços sem oclusão. A diluição foi deixada em contato com a pele durante 1 minuto antes da remoção. Uma área semelhante mas sem aplicação de MN no mesmo antebraço foi usada como controlo negativo. As variáveis funcionais da pele foram medidas por tecnologias não invasivas no tempo 0 (controlo) e após o contato com MN nos tempos 30, 60 e 120 minutos. 
Analytical technologies for the evalution of the effects of exposure were:

- Polarized Spectroscopy using the Tissue Viability Imaging system (TiVi 700, WheelsBridge $\mathrm{AB}$, Linköping, Sweden), which quantifies the concentration of red blood cells (CRBC - TiVi index), expressed in arbitrary units, in a previously selected region of interest (ROI);

- Laser Doppler Flowmetry (LDF, PeriFlux System 5000, Perimed AB, Järfälla, Sweden), which measures the perfusion expressed in arbitrary units of perfusion (PUs);

- Transepidermal Water Loss Meter, a direct indicator of "epidermal barrier" integrity, measured by evaporimetry (Tewameter TM300, CK electronics, Köln, Germany) and expressed as $\mathrm{g} /$ hour $/ \mathrm{m}^{2}$.

- High-resolution sonography (HRS) (Dermascan C, Cortex Technology, Hadsund, Denmark) providing a bidimensional color image recorded at a velocity of $1580 \mathrm{~m} / \mathrm{s}$, using a $20 \mathrm{MHz}$ probe placed on the skin in a fixed standard position (25). The color image was converted into a greyscale image for further analysis and processed by software Image $\mathrm{J}^{\circledR}$ (NIH, Bethesda, Maryland, USA).

Skin responses were also scored by direct observation using the International Contact Dermatitis Group Research (ICDRG) scale (26) adapted by Yulla et al., (3) (Table 1).

All measurements took place in a controlled humidity and temperature environment (humidity $\sim 50 \%$, temperature $21 \pm 2^{\circ} \mathrm{C}$ ) where participants were allowed to acclimatize for a minimum of 30 minutes prior to evaluations.
As tecnologias escolhidas foram

- Espectroscopia polarizada usando o sistema de imagem de viabilidade tecidual (TiVi 700, WheelsBridge AB, Linköping, Suécia) que quantifica a concentração de hemácias (CRBC índice TiVi), expressa em unidades arbitrárias, em uma região de interesse previamente selecionada (ROI);

- Fluxometria por laser Doppler (LDF, PeriFlux System 5000, Perimed AB, Järfälla, Suécia), que mede a perfusão expressa em unidades arbitrárias de perfusão (PU's);

- Medidor de Perda de Água Transepidérmico, um indicador direto da integridade da "barreira epidérmica", medido por evaporimetria (Tewameter TM300, CK Electronics, Köln, Alemanha) e expresso em $\mathrm{g} / \mathrm{hora} / \mathrm{m}^{2}$.

- Ultra-sonografia de alta resolução (USAR) (Dermascan C, Cortex Technology, Hadsund, Dinamarca) que forneceu uma imagem colorida bidimensional gravada a uma velocidade de 1580 $\mathrm{m} / \mathrm{s}$, usando uma sonda de $20 \mathrm{MHz}$ colocada na pele em uma posição padrão fixa (25). A imagem colorida foi convertida em uma imagem em escala de cinza para posterior análise e processamento pelo software Image ${ }^{\circledR}(\mathrm{NIH}$, Bethesda, Maryland, EUA).

As respostas cutâneas também foram pontuadas por observação direta usando a escala International Contact Dermatitis Group Research (ICDRG) (26) adaptada por Yulla et al., (3) (Tabela 1).

Todas as medições ocorreram em ambiente com umidade e temperatura controladas (umidade $\sim 50 \%$, temperatura $21+2{ }^{\circ} \mathrm{C}$ ) onde os participantes puderam se aclimatar por pelo menos 30 minutos antes das avaliações.

Table 1 - ICDRG criteria for assessing skin sensitization potential provoked by different chemical agents (adapted from Yulla et al., 2019)

Tabela 1 - Critérios do ICDRG para avaliar o potencial de sensibilização da pele provocada por diferentes agentes químicos (adaptado de Yulla et al., 2019)

\begin{tabular}{ccc}
\hline Criterion / Critério & ICDRG & Notation Score / Notação de Score \\
\hline No reaction / Não reativo & 0 & 0 \\
Doubtful reaction / Reação duvidosa & \pm & 0.5 \\
Erythema and edema / Eritema e edema & + & 1 \\
Erythema, oedema, and vesicles / Eritema, edema, e vesículas & ++ & 2 \\
Severe reaction with blisters / Reação severa com bolhas & +++ & 3 \\
\hline
\end{tabular}




\section{Statistics}

Data reported as mean \pm standard error of the mean (SEM) were compared by the Wilcoxon signed-rank test using GraphPadPrism $5^{\circledR}$ software (GraphPad software, San Diego, CA, USA). A $p$ value $<0.05$ was considered significant in all experiments.

\section{Results and Discussion}

The clinical evaluation with the ICDRG score scale revealed that both $\mathrm{MN}$ dilutions significantly increased the score after 30 minutes $(1.5 \pm 0.19$ and $1.37 \pm 0.18$ for $0.5 \%$ and $1.0 \%$, respectively). The reaction was visually much more intense at 30 minutes, decreasing almost to the baseline after 60 and 120 minutes (Figure 1).

The TEWL increase suggests that MN disturbed the epidermal skin barrier function (Figure 2) while highresolution sonography (HRS) revealed an increased dermal hypoecogenicity which is suggestive of edema formation (Figures 3 and 4). The skin barrier changes were expected and have been previoulsly reported (27). However, the presence of edema, confirming

\section{Estatística}

Os dados foram reportados como média \pm erro padrão da média (SEM). A comparação foi feita pelo teste não-paramétrico de Wilcoxon usando o software GraphPadPrism5 ${ }^{\circledR}$ (Software GraphPad, San Diego, CA, EUA). Um valor de $p<0,05$ foi considerado significativo em todos os experimentos.

\section{Resultados e Discussão}

A avaliação com a escala de pontuação do ICDRG revelou que ambas as diluições de $\mathrm{MN}$ aumentaram significativamente a pontuação após 30 minutos $(1,5 \pm$ 0,19 e $1,37 \pm 0,18$ para $0,5 \%$ e $1,0 \%$, respectivamente). Visualmente, a reação foi muito mais intensa em 30 minutos, diminuindo quase até a linha de base após 60 e 120 minutos (Figura 1).

$\mathrm{O}$ aumento da PTEA sugere que o MN perturbou a função de barreira cutânea epidérmica (Figura 2), enquanto a ultrassonografia de alta resolução (USAR) revelou um aumento da hipoecogenicidade dérmica que é sugestiva de formação de edema (Figuras 3 e 4). As alterações da barreira cutânea eram esperadas e já foram relatadas anteriormente (27). No entanto, a presença

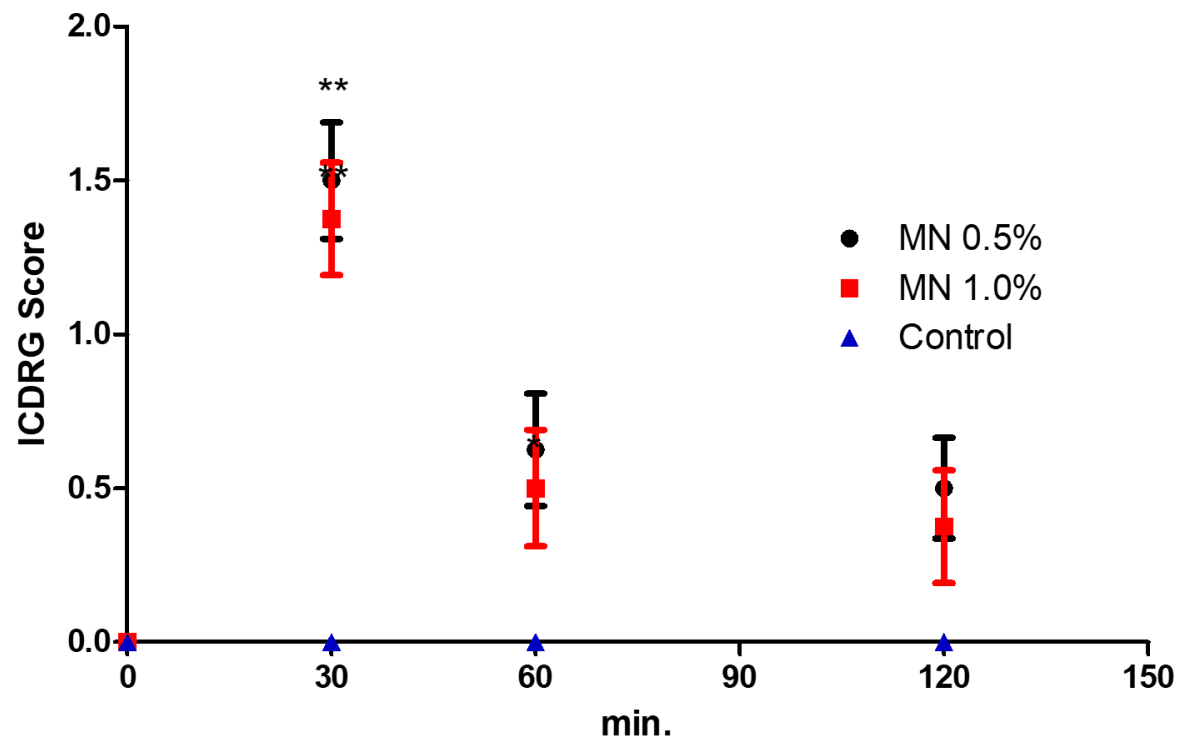

Figure 1 - Effects of MN $0.5 \%$ and $1.0 \%$ on ICDRG score in the different time of observation. Statistical comparison was performed using Wilcoxon signed-rank test. ${ }^{* *} p<0.01$ when compared to the control site.

Figura 1 - Efeitos de MN 0,5\% e 1,0\% no score ICDRG nos diferentes tempos de observação. A comparação estatística foi realizada usando o teste não paramétrico de Wilcoxon. ${ }^{* *} p<0,01$ quando comparado ao controlo negativo. 
a cardinal sign of inflammation, as detected by HRS images, have not been previously described under the present experimental conditions. Consistent skin microcirculatory changes were also detected by both LDF and TIVI systems (Figures 5 and 6).

Skin irritation and inflammation are common components of the dermatology glossary used to describe responses to a wide variety of chemical, physical, or biological stimuli. Often its significance is not very clear, being conversely used in distinct clinical processes. Skin barrier disruption, induction of a cytokine cascade, and involvement of oxidative stress are the main pathological alterations observed after cutaneous aggression resulting in a visible or subclinical inflammatory reaction $(12,28)$. Additionally, a strong interindividual variability response to irritants is recognised, but when there is sufficient exposure and high concentrations of the irritant, all individuals are prone to develop this cutaneous reaction $(12,28,29)$.

Our approach suggests that $\mathrm{MN}$ application evokes a consistent change of all the skin, from the epidermal barrier to the dermal plexus. This vasodilation is known, described as painless, short-term, and reproducible when evaluated in the same person using the same dose and application site (30). However, the peak response for this vasodilation and, all other parameters as well, occurred at 30 minutes after $\mathrm{MN}$ application and, although not de edema, confirmando um sinal cardinal principal de inflamação, detectado pelas imagens de HRS, não foi descrita antes, nas condições experimentais atuais. Foram observadas também alterações consistentes da microcirculação da pele detectadas pelos sistemas LDF e TIVI (Figuras 5 e 6 ).

A irritação e a inflamação da pele são componentes comuns do glossário dermatológico usado para descrever as respostas a uma ampla variedade de estímulos químicos, físicos ou biológicos. Frequentemente, seu significado não é tão claro, sendo usados inversamente em processos clínicos distintos. Ruptura da barreira cutânea, indução de cascata de citocinas e envolvimento do stresse oxidativo são as principais alterações patológicas observadas após agressão cutânea resultando em reação inflamatória visível ou subclínica $(12,28)$. Além disso, uma grande variabilidade de resposta interindividual aos irritantes é conhecida, mas quando há exposição suficiente e alta concentração do irritante, todos estão propensos a desenvolver essa reação cutânea $(12,28,29)$.

Nossa abordagem sugere que a aplicação de MN evoca uma mudança consistente de toda a pele, desde a barreira epidérmica ao plexo dérmico. Essa vasodilatação é conhecida, descrita como indolor, de curta duração e reproduzível quando avaliada na mesma pessoa na mesma dose e local de aplicação (30). No entanto, o

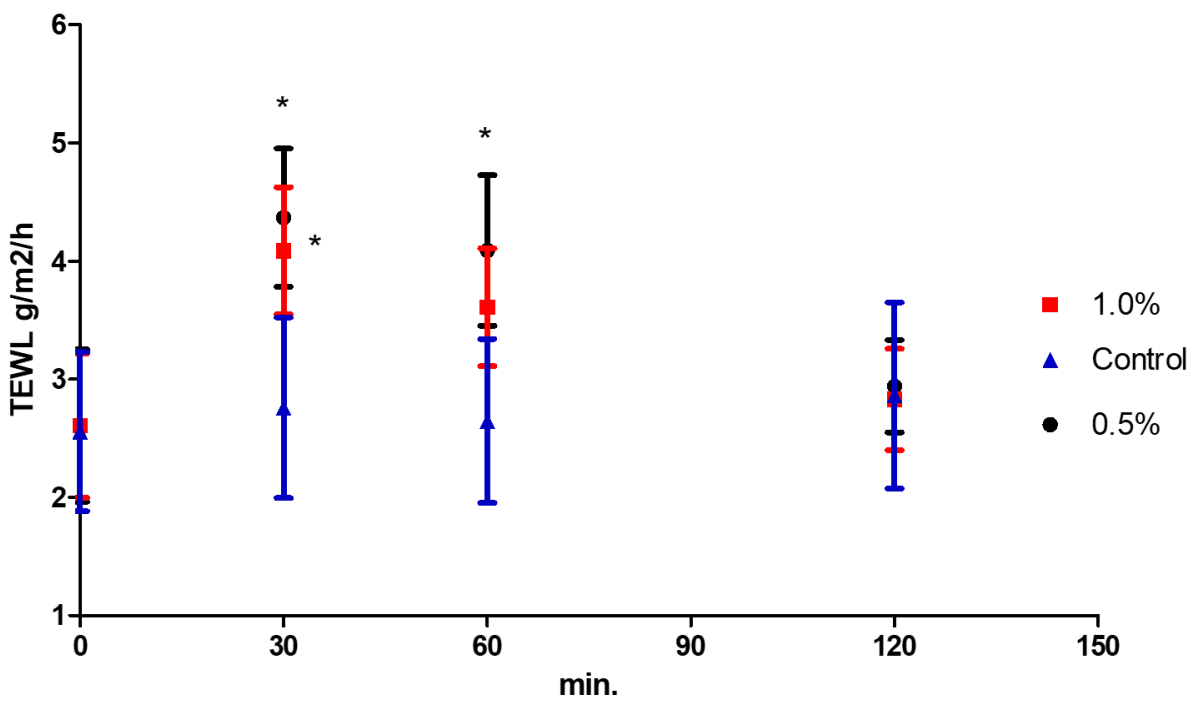

Figure 2 - Effects of MN $0.5 \%$ and $1.0 \%$ on Transepidermal water loss (TEWL) in the different times of measurement. Statistical comparison was performed using Wilcoxon signed-rank test. ${ }^{*} p$ $<0.05$ when compared to the control site.

Figura 2 - Efeitos do MN 0,5\% e 1,0\% na perda transepidérmica de água (PTEA) nos diferentes tempos de medição. A comparação estatística foi realizada usando o teste não-paramétrico de Wilcoxon. ${ }^{*} p<0,05$ quando comparado ao controlo negativo. 


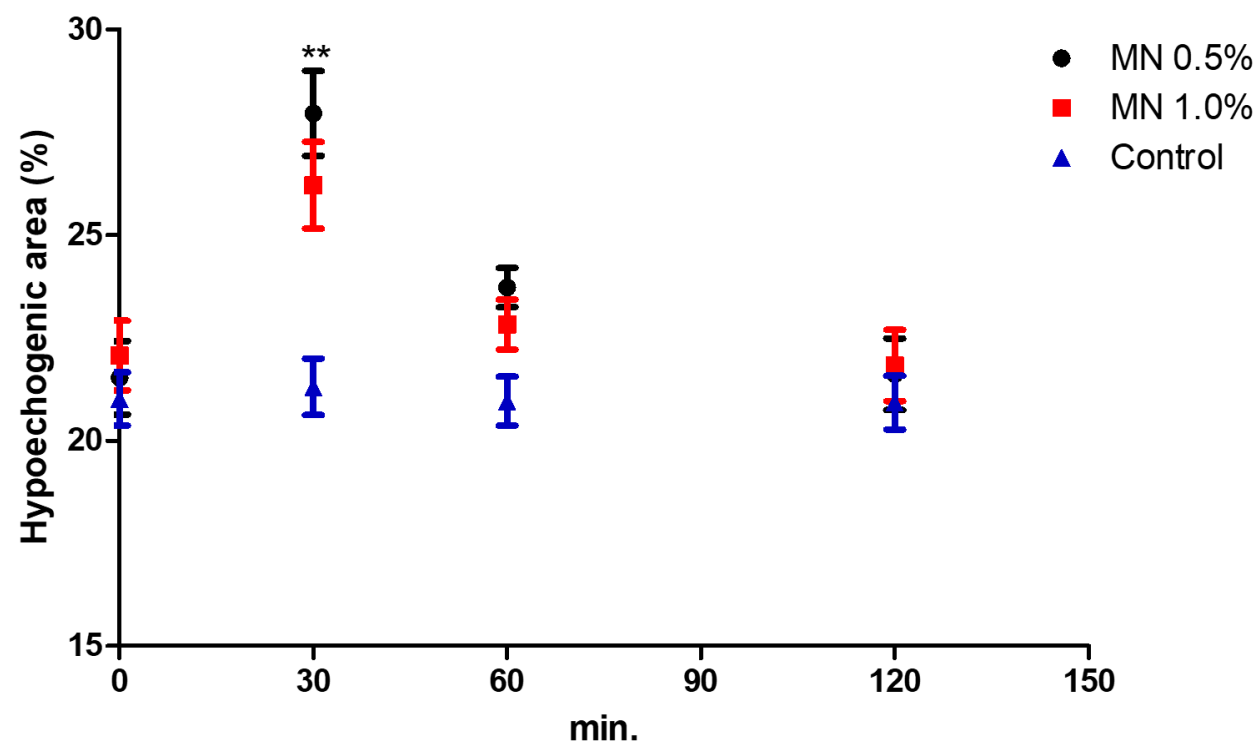

Figure 3 - Effects of MN $0.5 \%$ and $1.0 \%$ on skin hypoechogenicity in the different time of measurement. Statistical comparison was performed using Wilcoxon signed-rank test. ${ }^{* *} p<0.01$ when compared to the control site.

Figura 3 - Efeitos do MN 0,5\% e 1,0\% na hipoecogenicidade da pele nos diferentes tempos de medição. A comparação estatística foi realizada usando o não-paramétrico de Wilcoxon. ${ }^{* *} p<$ 0,01 quando comparado ao controlo negativo.

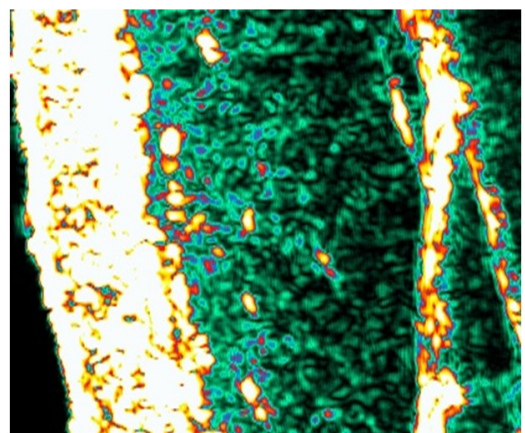

EPI

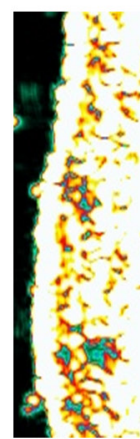

EPI

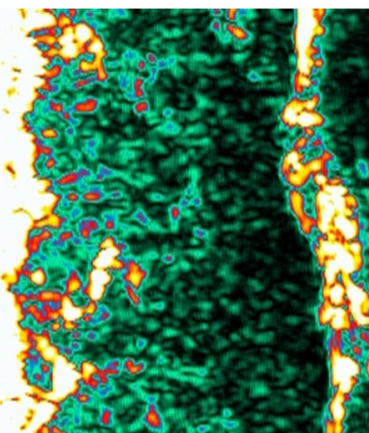

DER

$1.0 \mathrm{MN}$

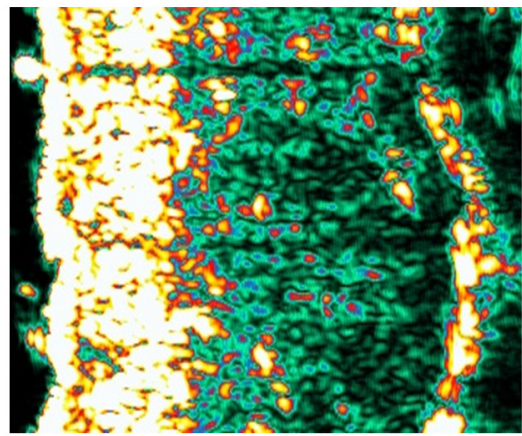

EPI

DER

$0.5 \mathrm{MN}$

Figure 4 - Illustrative example of the impact of application of MN solution $0.5 \%$ and $1.0 \%$ on the sonographic structure of one volunteer's skin. Images obtained by HRS 30 minutes after the application, shows an increase of the hypoechogenicity. EPI= epidermal layer; DERM= dermis. Figura 4 - Exemplo ilustrativo do impacto da aplicação de solução MN 0,5\% e 1,0\% na estrutura ultrassonográfica da pele de um voluntário. Imagens obtidas pelo USAR 30 minutos após a aplicação, mostram aumento da hipoecogenicidade. EPI = camada epidérmica; DERM = derme. 


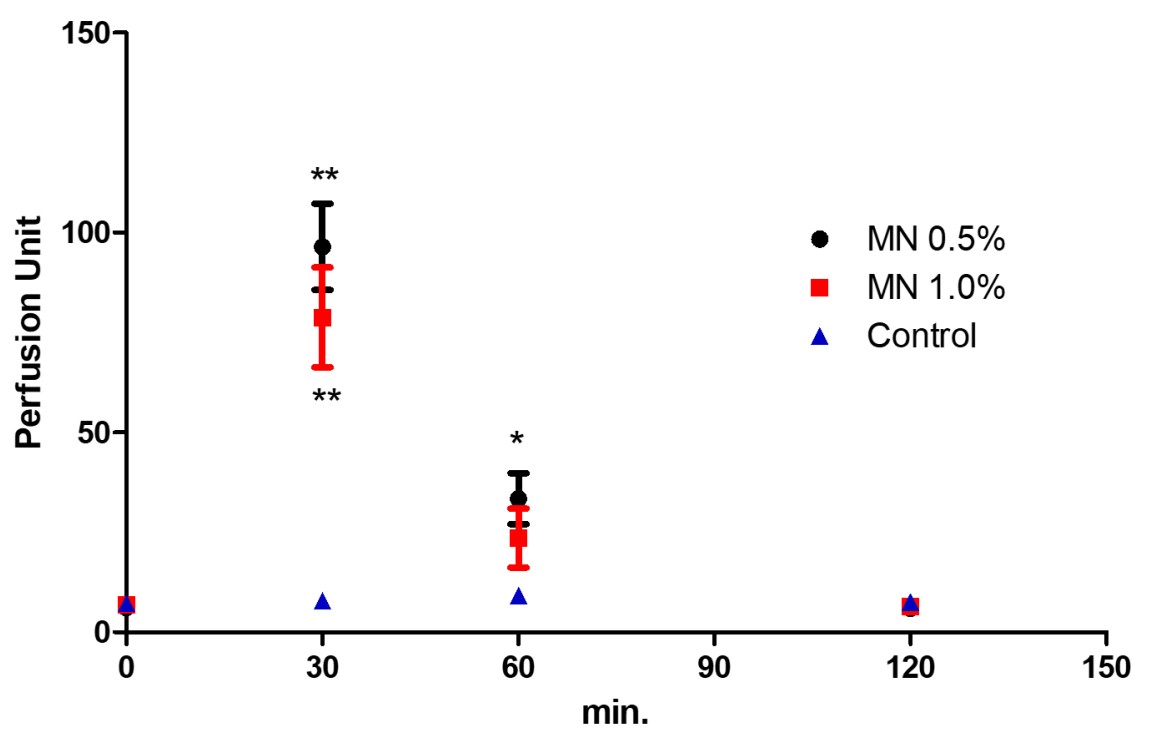

Figure 5 - Effects of $\mathrm{MN} 0.5 \%$ and $1.0 \%$ on skin microcirculation in the different time of measurement. Register was done with Laser Doppler Flowmetry (LDF). Statistical comparison was performed using Wilcoxon signed-rank test. ${ }^{*} p<0.01,{ }^{*} p<0.05$ when compared to the control site.

Figura 5 - Efeitos do MN 0,5\% e 1,0\% na microcirculação da pele nos diferentes tempos de medição. O registo foi feito com Fluxometria por Laser Doppler (LDF). A comparação estatística foi realizada usando o teste não-paramétrico de Wilcoxon. ${ }^{* *} p<0,01,{ }^{*} p<0,05$ quando comparado ao controlo negativo.

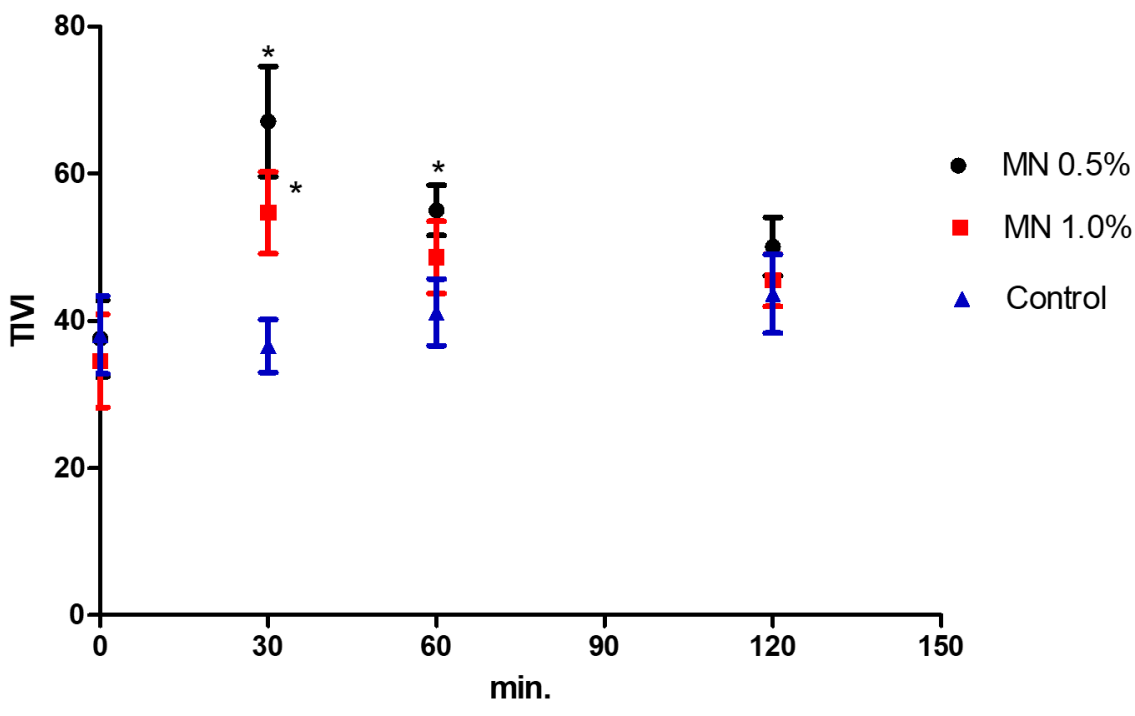

Figure 6 - Effects of MN $0.5 \%$ and $1.0 \%$ on skin microcirculation in the different time of measurement. Register was done with Polarized Light (TIVI device) Statistical comparison was performed using Wilcoxon signed-rank test. $* p<0.05$ when compared to the control site.

Figura 6 - Efeitos do MN 0,5\% e 1,0\% na microcirculação da pele nos diferentes tempos de medição. O registo foi feito com Espectroscopia polarizada usando o sistema de imagem de viabilidade tecidual (dispositivo TIVI). A comparação estatística foi realizada usando o teste nãoparamétrico de Wilcoxon. ${ }^{*} p<0,05$ quando comparado ao controlo negativo. 
significant, we noticed a trend for the highest response at the lowest concentration (MN 0.5\% solution). These results are inline with similar observations $(31,32)$ but the opposite has also been described (11). The presence of a localised edema, only detected by the HRS, suggests a short duration inflammatory process that might be mediated by prostaglandins with neurogenic components since histamine and nitric oxide might not be involved in this process $(15,31)$.

\section{Conclusion}

Our results contribute to a better understanding of the impact of $\mathrm{MN}$ on human skin and its interest as an experimental challenger. Even in lowe concentrations, $\mathrm{MN}$ is capable of modifying the entire cutaneous structure for a short period of time. This seems to be particularly suitable for safety and efficacy studies involving the anti-inflammatory activity. Nevertheless, more studies are needed to better understand and control $\mathrm{MN}$ mechanisms of action.

\section{Authors Contributions Statement}

LMR and SFA conceptual design; SFA and CR experimental and data analysis; SFA and LMR drafted and wrote the manuscript in its final version.

\section{Acknowledgements}

This research is funded by Fundação para a Ciência e a Tecnologia (FCT) through grant UIDB/04567/2020 to CBIOS. Sérgio Faloni de Andrade is funded by Foundation for Science and Technology (FCT) Scientific Employment Stimulus contract with the reference number CEEC/CBIOS/PMHD/2018.

\section{Conflict of Interests}

Editors involved in this manuscripts' authorship had no participation in the review or decision process. All authors have stated that there are no financial and/or personal relationships that could represent a potential conflict of interest. pico de resposta para essa vasodilatação e, também, para todos os outros parâmetros, ocorreu 30 minutos após a aplicação do $\mathrm{MN}$ e, embora não significativa, notamos uma tendência para a maior resposta na concentração mais baixa (solução MN 0,5\%). Esses resultados estão em linha com observações semelhantes $(31,32)$, mas o oposto também foi descrito (11). A presença de edema localizado, detectado apenas pelo USAR, sugere um processo inflamatório de curta duração que pode ser mediado por prostaglandinas com componentes neurogênicos, uma vez que a histamina e o óxido nítrico parecem não estar envolvidos neste processo $(15,31)$.

\section{Conclusão}

Nossos resultados contribuem para entender melhor o impacto do MN na pele humana e seu interesse como um desafiante experimental. Mesmo em pequenas concentrações, o MN é capaz de modificar toda a estrutura cutânea por um curto período de tempo. Isso parece ser particularmente adequado para estudos de segurança e eficácia envolvendo a atividade antiinflamatória. No entanto, mais estudos são necessários para melhor compreender e controlar os mecanismos de ação do MN.

\section{Declaração de contribuições dos autores}

LMR e SFA planejaram os experimentos; SFA e CR fizeram a coleta e análise dos dados; SFA e LMR redigiram e escreveram o manuscrito em sua versão final.

\section{Agradecimentos}

Esta investigação é financiada pela Fundação para a Ciência e a Tecnologia (FCT) através da bolsa UIDB / 04567/2020 do CBIOS. Sérgio Faloni de Andrade é financiado pela Fundação para a Ciência e Tecnologia (FCT) - Contrato de Estímulo ao Emprego Científico com o número de referência CEEC / CBIOS / PMHD / 2018.

\section{Conflito de interesses}

Os editores envolvidos na autoria deste manuscrito não participaram do processo de revisão ou decisão. Todos os autores afirmam que não existem relações financeiras e/ou pessoais que possam representar um potencial conflito de interesses. 


\section{References / Referências}

1. Kanitakis, J. (2002). Anatomy, histology and immunohistochemistry of normal human skin. European Journal of Dermatology, 12(4), 390401.

2. Hänel, K., Cornelissen, C., Lüscher, B., \& Baron, J. (2013). Cytokines and the Skin Barrier. International Journal of Molecular Sciences, 14(4), 6720-6745. doi: 10.3390/ijms14046720

3. Vidal Yucha, S., Tamamoto, K., \& Kaplan, D. (2019). The importance of the neuro-immuno-cutaneous system on human skin equivalent design. Cell Proliferation, 52(6), e12677. doi: 10.1111/cpr.12677

4. Scrivo, R., Vasile, M., Bartosiewicz, I., \& Valesini, G. (2011). Inflammation as "common soil" of the multifactorial diseases. Autoimmunity Reviews, 10(7), 369-374. doi: 10.1016/j.autrev.2010.12.006

5. Medzhitov, R. (2008). Origin and physiological roles of inflammation. Nature, 454(7203), 428-435. doi: 10.1038/nature07201

6. de Almeida Roediger, M., de Fátima Nunes Marucci, M., Duim, E., Santos, J., de Oliveira Duarte, Y., \& de Oliveira, C. (2019). Inflammation and quality of life in later life: findings from the health, well-being and aging study (SABE). Health And Quality Of Life Outcomes, 17(1),26. doi: 10.1186/s12955-019-1092-2

7. Milam, E., \& Rieder, E. (2021). An Approach to Cosmeceuticals. Essential Psychiatry For The Aesthetic Practitioner, 42-48.

8. Tetali, B., Fahs, F., \& Mehregan, D. (2019). Popular over-the-counter cosmeceutical ingredients and their clinical efficacy. International Journal Of Dermatology, 59(4), 393-405. doi: 10.1111/ijd.14718

9. Hoffmann, S., Kleinstreuer, N., Alépée, N., Allen, D., Api, A., \& Ashikaga, T. et al. (2018). Non-animal methods to predict skin sensitization (I): the Cosmetics Europe database. Critical Reviews In Toxicology, 48(5), 344-358. doi: 10.1080/10408444.2018.1429385

10. Robinson, M., Cohen, C., de Fraissinette, A., Ponec, M., Whittle, E., \& Fentem, J. (2002). Non-animal testing strategies for assessment of the skin corrosion and skin irritation potential of ingredients and finished products. Food And Chemical Toxicology, 40(5), 573-592. doi: $10.1016 / \mathrm{s} 0278-6915(02) 00005-4$

11. Jumbelic, L., Liebel, F., \& Southall, M. (2006). Establishing a Minimal Erythema Concentration of Methyl Nicotinate for Optimum Evaluation of Anti-Inflammatories. Skin Pharmacology And Physiology, 19(3), 147-152. doi: 10.1159/000092595

12. Fluhr, J., Akengin, A., Bornkessel, A., Fuchs, S., Praessler, J., \& Norgauer, J. et al. (2005). Additive impairment of the barrier function by mechanical irritation, occlusion and sodium lauryl sulphate in vivo. British Journal Of Dermatology, 153(1), 125-131. doi: 10.1111/j.13652133.2005.06430.x

13. Tupker, R., Willis, C., Berardksca, E., Lee, C., Fartasch, M., Atinrat, T., \& Serup, J. (1997). Guidelines on sodium lauryl sulfate (SLS) exposure tests. Contact Dermatitis, 37(2), 53-69. doi: 10.1111/j.1600-0536.1997.tb00041.x

14. Tadić, V., Arsić, I., Zvezdanović, J., Zugić, A., Cvetković, D., \& Pavkov, S. (2017). The estimation of the traditionally used yarrow ( Achillea millefolium L. Asteraceae) oil extracts with anti-inflamatory potential in topical application. Journal Of Ethnopharmacology, 199, 138-148. doi: 10.1016/j.jep.2017.02.002

15. Elawa, S., Mirdell, R., Farnebo, S., \& Tesselaar, E. (2019). Skin blood flow response to topically applied methyl nicotinate: Possible mechanisms. Skin Research And Technology, 26(3), 343-348. doi: 10.1111/srt.12807

16. Lee, C., Kim, H., Han, H., \& Park, C. (2004). A Comparison Study of Nonanoic Acid and Sodium Lauryl Sulfate in Skin Irritation. Exogenous Dermatology, 3(1), 19-25. doi:10.1159/000084139

17. Gabard, B., Chatelain, E., Bieli, E., \& Haas, S. (2001). Surfactant irritation: in vitro corneosurfametry and in vivo bioengineering. Skin Research And Technology, 7(1), 49-55. doi: 10.1034/j.1600-0846.2001.007001049.x

18. Pinto, PC., Martinho, H., \& Rodrigues L.M. (2007) Studying the influence of the phototype over human skin's response to Sodium Lauril Sulfate contact in vivo, Revista Saúde \& Tecnologia, (4)1, 47-56.

19. Morrow, J., Parsons, W., \& Roberts, L. (1989). Release of markedly increased quantities of prostaglandin D2 in humans following the administration of nicotinic acid. Prostaglandins, 38(2), 263-274. doi: 10.1016/0090-6980(89)90088-9

20. Guy, R., \& Maibach, H. (1982). Rapid radial transport of methyl nicotinate in the dermis. Archives Of Dermatological Research, 273(1-2), 91-95. doi: 10.1007/BF00509031

21. Guy, R., Tur, E., Bjerke, S., \& Maibach, H. (1985). Are there age and racial differences to methyl nicotinate-induced vasodilatation in human skin? Journal Of The American Academy Of Dermatology, 12(6), 1001-1006. doi: 10.1016/s0190-9622(85)70128-4

22. Leoty-Okombi, S., Gillaizeau, F., Leuillet, S., Douillard, B., Le Fresne-Languille, S., \& Carton, T. et al. (2021). Effect of Sodium Lauryl Sulfate (SLS) Applied as a Patch on Human Skin Physiology and Its Microbiota. Cosmetics, 8(1), 6. doi: 10.3390/cosmetics8010006

23. De Jongh, C., Verberk, M., Withagen, C., Jacobs, J., Rustemeyer, T., \& Kezic, S. (2006). Stratum corneum cytokines and skin irritation response to sodium lauryl sulfate. Contact Dermatitis, 54(6), 325-333. doi: 10.1111/j.0105-1873.2006.00848.x.

24. World Medical Association Declaration of Helsinki. (2013). JAMA, 310(20), 2191. doi: 10.1001/jama.2013.281053

25. Seidenari, S., Nakijo, A., Pepe, P., \& Giannetti, A. (1991). Ultrasound B scanning with image analysis for assessment of allergic patch test reactions. Contact Dermatitis, 24(3), 216-222. doi: 10.1111/j.1600-0536.1991.tb01701.x

26. Marzulli, F., \& Maibach, H. (1976). Contact allergy: Predictive testing in man. Contact Dermatitis, 2(1), 1-17. doi: 10.1111/j.16000536.1976.tb02972.x

27. Ratz-lyko, A., Arct, J., \& Pytkowska, K. (2016). Moisturizing and antiinflammatory properties of cosmetic formulations containing Centella asiatica extract. Indian Journal Of Pharmaceutical Sciences, 78(1), 27. doi: 10.4103/0250-474x.180247

28. Fluhr, J., Darlenski, R., Angelova-Fischer, I., Tsankov, N., \& Basketter, D. (2008). Skin Irritation and Sensitization: Mechanisms and New Approaches for Risk Assessment. Skin Pharmacology And Physiology, 21(3), 124-135. doi: 10.1159/000135635

29. Sasseville, D. (2008). Occupational Contact Dermatitis. Allergy, Asthma, And Clinical Immunology, 4(2), 59-65. doi: 10.1186/1710-14924-2-59

30. Poelman, M., Piot, B., Guyon, F., Deroni, M., \& Leveque, J. (1989). Assessment of topical non-steroidal anti-inflammatory drugs. Journal Of Pharmacy And Pharmacology, 41(10), 720-722. doi: 10.1111/j.2042-7158.1989.tb06350.x

31. Vertuani, S., Ziosi, P., Solaroli, N., Buzzoni, V., Carli, M., \& Lucchi, E. et al. (2003). Determination of antioxidant efficacy of cosmetic formulations by non-invasive measurements. Skin Research And Technology, 9(3), 245-253. doi: 10.1034/j.1600-0846.2003.00018.x 